\title{
Sixteen vetted fossil calibrations for divergence dating of Charadriiformes (Aves, Neognathae)
}

\author{
N. Adam Smith
}

\begin{abstract}
The Charadriiformes (shorebirds and allies) are an ecologically and morphologically diverse clade with a global geographic distribution. The perceived antiquity of this lineage and the cryptic plumage and morphology of some charadriforms have made them a frequent focus of study by ornithologists. Likewise, with the relatively recent advent of molecular sequence based divergence estimation methods, no less than seven studies have estimated the timing of cladogenetic events in Charadriiformes. Unfortunately, all of those studies have suffered from poor choice and characterization (i.e., age and taxonomic assignment) of fossil calibrations used for divergence time analysis. Given that studies of both real and simulated data have demonstrated the potential for calibration choice to bias node age estimates, the results of previously published analyses of divergence times for Charadriiformes must, accordingly, be viewed with caution. To alleviate introduction of fossil calibration bias with respect to future analyses of divergence times including Charadriformes, 16 rigorously evaluated charadriiform fossil calibrations are reported herein.
\end{abstract}

N. Adam Smith. The National Evolutionary Synthesis Center, 2024 W. Main St., Suite A200, Durham, NC, 27705, U.S.A., adam_smith@utexas.edu

KEYWORDS: Charadrii; minimum age constraints; Pan-Alcidae; Lari; Scolopaci; seabirds and shorebirds

\section{INTRODUCTION}

Charadriiformes (shorebirds and allies) are a globally distributed clade including more than 360 morphologically and ecologically diverse species (del Hoyo et al., 1996). In part because charadrii- forms were previously considered a basal neornithine lineage and were influential in the development of the largely refuted 'transitional shorebird' hypothesis (Olson, 1985; Feduccia, 1996), dating cladogenetic events in Charadrii-

PE Article Number: 18.1.4FC

Copyright: Society for Vertebrate Paleontology February 2015

Submission: 3 June 2013. Acceptance: 23 August 2013

Smith, N. Adam. 2015. Sixteen vetted fossil calibrations for divergence dating of Charadriiformes (Aves, Neognathae). Palaeontologia Electronica 18.1.4FC; 1-18;

palaeo-electronica.org/content/fc-4

Calibrations published in the Fossil Calibration Series are accessioned into the Fossil Calibration Database (www.fossilcalibrations.org). The Database is a dynamic tool for finding up-to-date calibrations, and calibration data will be updated and annotated as interpretations change. In contrast, the Fossil Calibration papers are a permanent published record of the information on which the calibrations were originally based. Please refer to the Database for the latest data. 
formes has remained a topic of considerable interest. Consequently, there have been at least seven divergence time estimates that have included or focused on this clade (or charadriiform subclades) in recent years (Paton et al., 2002; Paton et al., 2003; Pereira and Baker, 2006; Ericson et al. 2006; Brown et al., 2007; Baker et al., 2007; Weir and Mursleen, 2012). Those analyses have utilized different data (i.e., a variety of mitochondrial and nuclear genes), varied in the choice, age assignments, and types of calibrations applied (e.g., secondary external and/or internal fossil calibrations), and have used multiple types of dating software (reviewed by Smith, 2011a). Not surprisingly, previous divergence time analyses have recovered ages ranging from $\sim 57-108 \mathrm{Ma}$ for the basal divergence among crown Charadriiformes. Although methodological issues are certainly responsible for some portion of the magnitude of variation in recovered dates, choice of fossil calibrations and the prior age information assigned to fossils used as calibrations has no doubt contributed to the discrepancy between previous analyses of the clade (Mayr, 2011; Smith, 2011a; Parham et al., 2012; Smith and Clarke, in press). To alleviate uncertainty related to choice and age assignments of fossil calibrations in future divergence analyses including charadriiforms, 16 rigorously evaluated charadriiform calibrations are described herein.

\section{METHODS}

Fossil calibration criteria follow Parham et al. (2012). Names and ages of geologic intervals follow the International Geologic Time Scale (International Commission on Stratigraphy, 2012). Node numbers following the "Node Calibrated" headings refer to nodes labeled on the phylograms depicted in Figures 1 and 2.

\section{CLADE CHARADRIIFORMES}

Node Calibrated (1): Charadriiformes (shorebirds and allies). Divergence of the clade Charadriiformes (shorebirds and allies) from its nearest outgroup (see below for discussion of outgroup; Figure 1).

Fossil Taxon. Charadriiformes incertae sedis Mayr, 2000.

Specimen. SMF-ME 2458A+B (Forschungsinstitut Senckenberg, Frankfurt, Germany) partial postcranial skeleton.

Phylogenetic Justification. SMF-ME $2458 A+B$ was referred to Charadriiformes by Mayr (2000) based on apomorphies of the coracoid, humerus and carpometacarpus. The following apomorphies that support referral of SMF-ME 2458A+B were cited by Mayr (2000:626): (1) coracoid with protruding tuberculum brachiale and broad facies articularis clavicularis; (2) furcula with long and slender processus acromialis (except Burhinidae); (3) humerus with more or less well developed processus supracondylaris dorsalis (except Alcidae, Burhinidae, Jacanidae); (4) synsacrum perforated by many foramina intertransversaria; (5) crista cnemialis cranialis of tibiotarsus greatly enlarged; (6) fourth phalanx of fourth toe shorter than third phalanx (except Alcidae); (7) hallux strongly reduced or absent (except Jacanidae). However, the affinities of SMF-ME $2458 A+B$ within Charadriiformes (i.e., stem or crown) are uncertain because it has not been included in a phylogenetic analysis. No alternative hypothesis has been proposed linking this specimen to any clade other than Charadriiformes.

Minimum Age. Middle Eocene (Lutetian) $46.5 \mathrm{Ma}$

Soft Maximum Age. Not specified

Age Justification. Igneous rocks from Messel were dated using ${ }^{40} \mathrm{Ar} / 39 \mathrm{Ar}$ methods to $47.8 \pm 0.2 \mathrm{Ma}$ and correspond with biostratigraphic reference level MP 11 (i.e., the base of the Geiseltalian European Land Mammal Age; Mertz and Renne, 2005). The span of the Geiseltalian is estimated at 47.5-46.5 Ma (Mertz and Renne, 2005).

Discussion. The systematic position of Charadriiformes among Aves is not unambiguously established because the results of analyses of higher-level phylogenetic relationships of Aves are incongruent (Mayr and Clarke, 2003; Hackett et al., 2008; Livezey and Zusi, 2006, 2007; Brown et al., 2007; Ericson et al., 2006), thus complicating the choice of a fossil calibration to date the split of Charadriiformes from its nearest outgroup. For example, if Charadriiformes are the sister taxon to the 'waterbird' clade as hypothesized by Brown et al., 2007, then the earliest known penguins, Waimanu manneringi and Waimanu tuatahi ( $\sim 61 \mathrm{Ma}$; Slack et al., 2006) might provide a calibration for that split. However, if Charadriiformes are the 


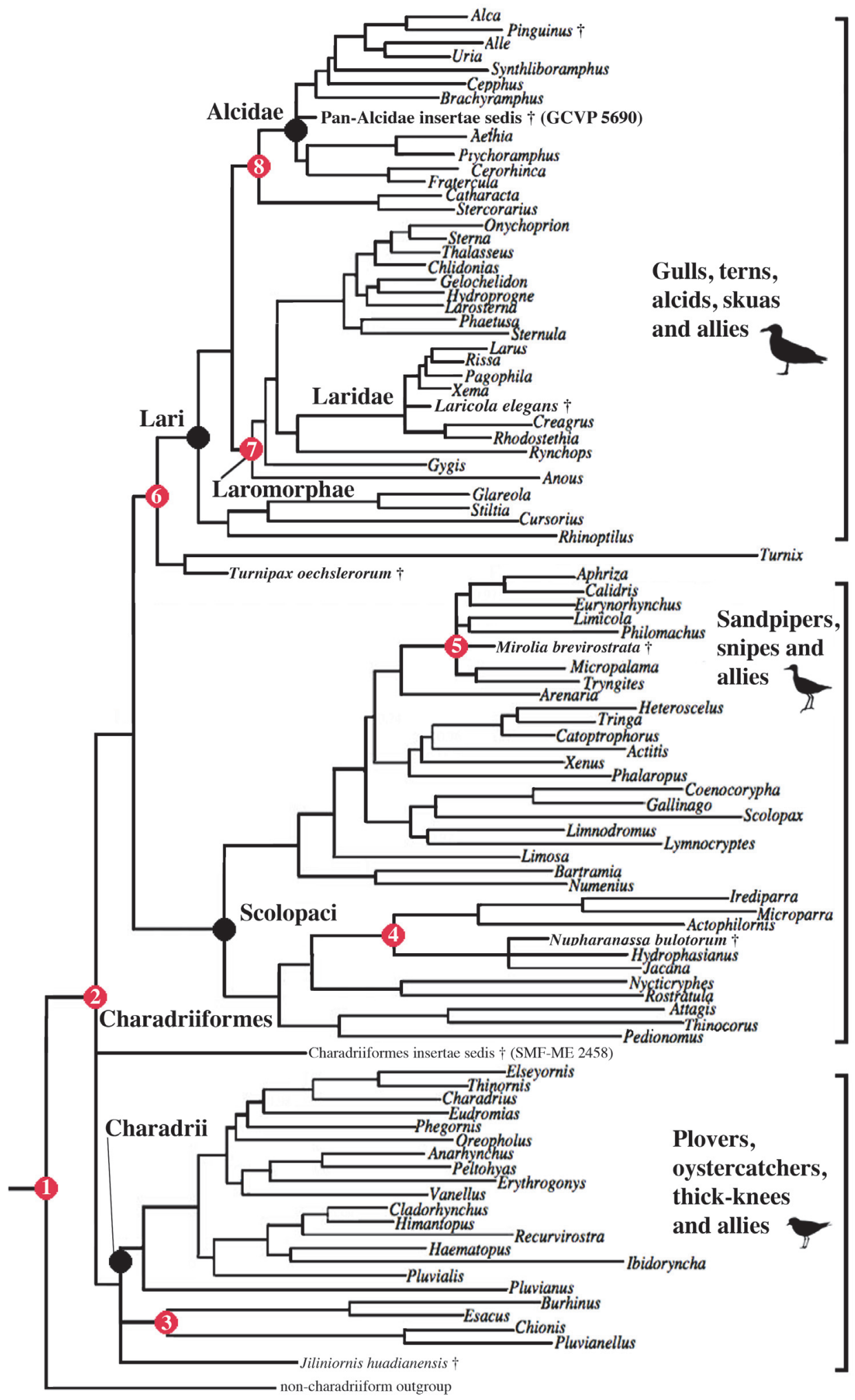

FIGURE 1. Phylogram of charadriiform relationships showing calibrated nodes 1-7 (modified from Baker et al., 2007, figure 1). Numbered nodes in red correspond to the following calibrations: (1) divergence of Charadriiformes from its nearest outgroup; (2) divergence of Charadrii from other Charadriiformes; (3) divergence of Burhinidae from Chionis and Pluvianellus; (4) divergence of Jacanidae from other Scolopaci; (5) basal divergence among Calidridinae; (6) divergence of Turnicidae from Lari; (7) basal divergence of Laromorphae; (8) divergence of Alcidae from Stercorariidae. 


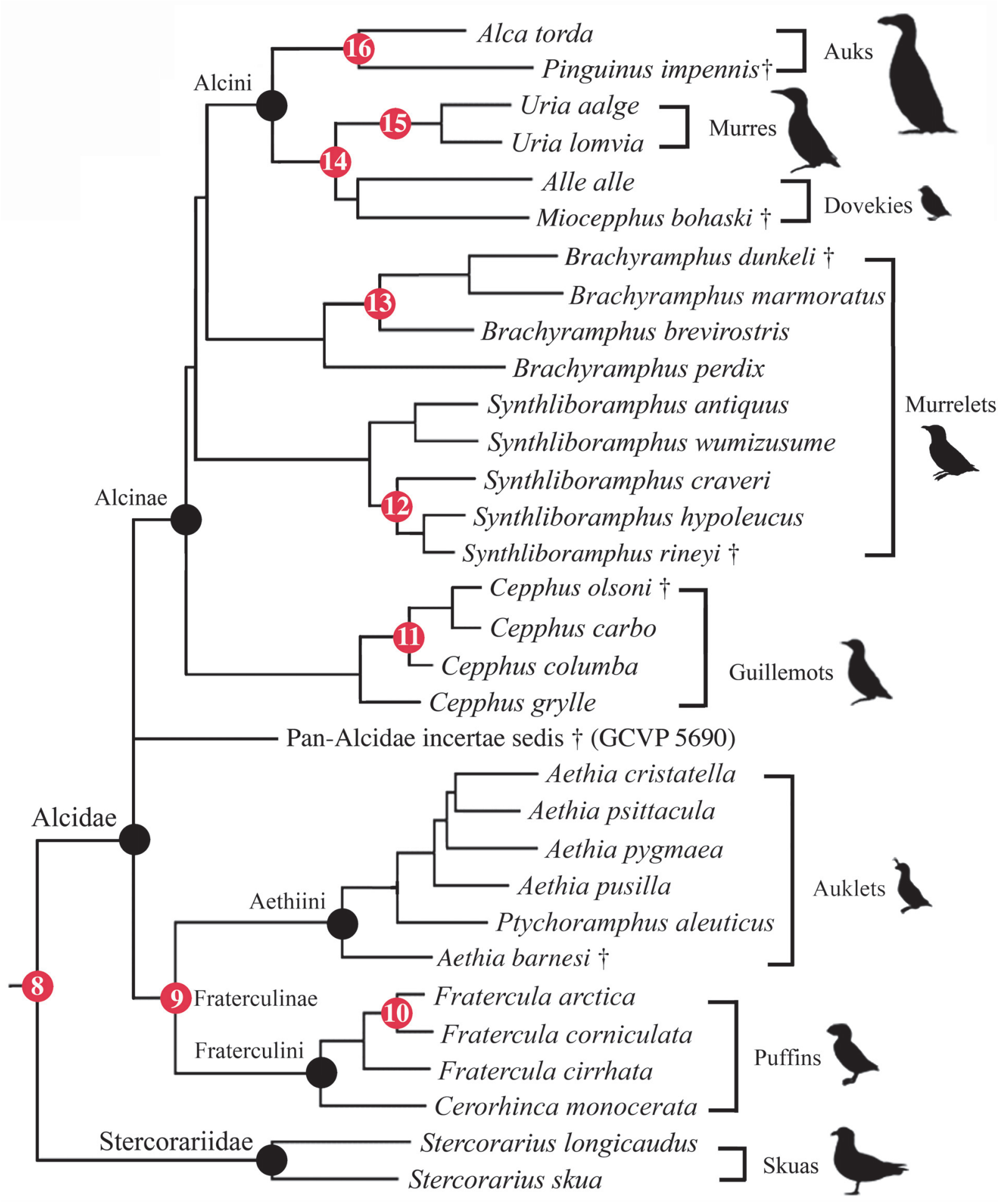

FIGURE 2. Phylogram of alcid relationships showing calibrated nodes 7-15 (modified from Smith, 2011a, figure 1.26). Numbered nodes in red correspond to the following calibrations: (8) divergence of Alcidae from Stercorariidae; (9) divergence of Aethiini from Fraterculini; (10) divergence of Fratercula arctica from Fratercula corniculata; (11) divergence of Cepphus carbo from Cepphus columba; (12) divergence of Synthliboramphus hypoleucus from Synliboramphus craveri;divergence of Synthliboramphus hypoleucus from Synthliboramphus craveri; (13) divergence of Brachyramphus marmoratus from Brachyramphus brevirostris; (14) divergence of Alle alle from Uria; (15) divergence of Uria lomvia from Uria aalge; (16) divergence of Alca torda from Pinguinus impennis. 
sister taxon to the 'landbird' clade as proposed by Hackett et al. (2008), the earliest 'landbird' fossil, that of the Late Paleocene (Thanetian, $56 \mathrm{Ma}$ ) owl Ogygoptynx wetmorei Rich and Bohaska 1976 might provide a calibration for the split between Charadriiformes and the 'landbird' clade. Because of the uncertainty associated with the establishment of the outgroup to Charadriiformes, a conservative strategy of using the earliest record of Charadriiformes is justified.

All Mesozoic and Paleocene fossils referred to Charadriiformes (e.g., Harrison and Walker, 1977; Olson and Paris, 1987) consist of unassociated and undiagnostic fragments (Hope, 2002; Clarke and Norell, 2002; Mayr, 2005). Records of charadriiforms from the Eocene include the German specimen listed above (Mayr, 2000), a Pan-Alcidae fossil from the Late Eocene ( $35 \mathrm{Ma}$ ) of eastern North America (Chandler and Parmley, 2002; see below), an isolated humerus from the Middle Eocene of China (Hou and Ericson, 2002; see below), and a putative charadriiform specimen from eastern North America (Olson, 1999). Early Eocene ( $\sim 33 \mathrm{Ma})$ material referred to Charadriiformes by Olson (1999) is considered too fragmentary for referral to Charadriiformes (Mayr, 2005). Therefore, SMF-ME 2458A+B represents the earliest definitive record of Charadriiformes. However, the possibility that SMFME 2458A+B represents the stem lineage of Charadriiformes cannot be excluded, and awaits its inclusion in a phylogenetic analysis with sufficiently sampled outgroup taxa to Charadriiformes.

Despite the uncertain affinities of putative charadriiforms from the Mesozoic and Paleocene, these fossils have been used as calibrations in previous divergence time analyses. For example, the list of fossil taxa used to constrain the age of the split of Charadriiformes from its nearest outgroup by Baker et al. (2007) and Pereira and Baker (2008) includes three species of Paleotringa, three species of Cimolopteryx, and Ceramornis major from the Late Cretaceous or Early Paleocene (see Baker et al., 2007, table S3). Ceramornis is considered to be Neornithes incertae sedis (Hope, 2002), and is therefore inappropri- ate for use as a charadriiform fossil calibration. The referral of Cimolopteryx to Charadriiformes is not certain (Hope, 2002). Accordingly, Cimolopteryx should not be used as a calibration point to date the basal divergence among charadriiforms. Baker et al. (2007) and Pereira and Baker (2008) used specimens referred to the Late Cretaceous or Early Paleocene taxon Paleotringa to date the minimum age of the Lari-Scolopaci split and the split of Charadriiformes from their outgroup respectively. Specimens referred to Paleotringa include isolated partial tibiotarsi, tarsometatarsi, and humeri (Brodkorb, 1967) and do not preserve any apomorphies that would allow their referral to Charadriiformes (Hope, 2002). Accordingly, continued use of Paleotringa to date the divergence of Charadriiformes from its nearest sister group, or to date the split between scolopacid and larid lineages is inadvisable.

\section{CLADE CROWN CHARADRIIFORMES}

Node Calibrated (2): crown Charadriiformes. Divergence of Charadrii (plovers and allies) from all other Charadriiformes (i.e., the split between Charadrii and clade including the Lari and Scolopaci; Figure 1)

Fossil Taxon. Jiliniornis huadianensis $\mathrm{Hou}$ and Ericson, 2002.

Specimen. IVPP V.8323 (Institute of Vertebrate Paleontology and Paleoanthropology, Beijing, China) holotype specimen of Jiliniornis huadianensis, humerus.

Phylogenetic Justification. The systematic position of Jiliniornis huadianensis was evaluated by Smith (2011a) in a combined analysis of morphological and molecular sequence data (Figure 1). Not surprisingly, given that it could only be scored for 26 of 365 characters, Jiliniornis huadianensis was placed in a polytomy near the base of Charadriiformes along with Scolopaci and Charadrii species in the strict consensus cladogram resulting from the analysis of that taxon and extant charadriiform species (Smith, 2011a, figure 8.7). No alternative hypothesis has been proposed linking this specimen to any clade other than Charadrii.

Minimum Age. Middle Eocene (Lutetian) 41.3 Ma Soft Maximum Age. Not specified Age Justification. Jiliniornis huadianensis was collected from the Middle Eocene Huadian Formation in the Jilin Province, China. Because the age 
of the Middle Eocene Huadian Formation is not precisely known a conservative approach was taken regarding the choice of the age prior on the node representing the split between Charadrii and the rest of the charadriiform crown clade. Although the holotype of Jiliniornis huadianensis may be older than latest Middle Eocene, an age of 41.3 $\mathrm{Ma}$, corresponding to the uppermost Middle Eocene boundary (Lutetian-Bartonian boundary) is suggested as a qualitative prior on the split between Charadrii and the rest of crown Charadriiformes.

Discussion. With the exception of the putative crown charadriiform from the Middle Eocene Messel Shale of Germany (discussed above), the earliest known crown charadriiform fossil is the humerus from the Middle Eocene Huadian Formation of Jilin Province, China. The holotype specimen of Jiliniornis huadianensis (IVPP V.8323) was tentatively referred to Charadrii by Hou and Ericson (2002) and the possibility that Jiliniornis huadianensis represents a stem charadriiform cannot be completely ruled out. However, Jiliniornis huadianensis was recovered nested within Charadriiformes in the analysis of Smith (2011a; i.e., not as sister to extant charadriiforms or stem Charadriiformes).

Charadrius sheppardianus was used by Baker et al. (2007) to date the split between Charadrius and Elseyornis + Thinornis. Not only was the date assigned to that taxon incorrect, but the affinities of Charadrius sheppardianus have not been confidently established (Olson, 1985; Smith, 2011a; Parham et al., 2012). The holotype of $C$. sheppardianus (AMNH 2576) was re-examined by Ksepka and Clarke (2009), who concurred with the designation of that specimen as Aves incertae sedis by Olson (1985). Therefore, Charadrius sheppardianus should not be used as a fossil calibration in future divergence analyses.

Vanellus selysii was used a prior on the divergence between Vanellus and other closely related Charadrii by Baker et al., (2007). However, the taxonomic affinities of Vanellus selysii have not been confidently established (Olson, 1985; Smith, 2011a).

\section{CLADE BURHINIDAE}

Node Calibrated (3): Burhinidae (stone curlews). Divergence of Burhinidae (i.e., Burhinus and Esacus) from Chionis (sheathbills) and Pluvianellus socialis (Magellanic Plover; Figure 1)
Fossil Taxon. Genucrassum bransatensis De Pietri and Scofield, 2013

Specimen. NMB Cod. 1258 (Natural History Museum Basel, Switzerland) holotype specimen of Genucrassum bransatensis, carpometacarpus.

Phylogenetic Justification. NMB Cod. 1258 was referred to Burhinidae by De Pietri and Scofield (2013) based on apomorphies of the carpometacarpus. The following apomorphies that support referral of NMB Cod. 1258 were cited by De Pietri and Scofield (2013): (1) strongly developed and ventrally projecting processus extensorius; (2) caudally well-developed ventral portion of trochlea carpalis, displaying a sharp angle distally. No alternative hypothesis has been proposed linking this specimen to any clade other than Burhinidae.

Minimum Age. Oligocene-Miocene boundary (Chattian-Aquatanian boundary) $23.03 \mathrm{Ma}$

\section{Soft Maximum Age. Not specified}

Age Justification. The Codret Quarry (CoderetBransat), from which the holotype of Genucrassum bransatensis was collected, is the reference locality for the Paleogene mammalian zone MP30. Zone MP30 is considered to bracket the MioceneOligocene boundary with an age estimated between 24.1-23.6 Ma (Hugueney et al., 2003). The age of the boundary between the Oligocene and Miocene has been revised to $23.03 \mathrm{Ma}$ (International Commission on Stratigraphy, 2012.) and is recommended herein as a constraint on the divergence between Burhinidae and other Charadrii.

Discussion. The fossil record of Burhinidae, and the early fossil record of Charadrii in general, is quite sparse (Mayr, 2009; De Pietri and Scofield, 2013). The next oldest record of Burhinidae is Burhinus lucorum from the early Miocene of North America (Bickart, 1981). Results of molecular sequence-based phylogenetic analyses (e.g., Baker et al., 2007; Figure 1) place Burhinidae as the sister taxon to a clade consisting of the Sheathbills (i.e., Burhinus and Esacus) and the monotypic genus Pluvianellus (i.e., Magellanic Plover $P$. socialis). In contrast, a recent morphology-based phylogenetic analysis recovered Burhinidae as the sister taxon to the monotypic plover genus Pluvianus (i.e., Egyptian Plover P. aegyptius; Mayr, 2011). If Burhinidae is the sister taxon to Pluvianus, rather than the sister taxon to Pluvianellus as represented herein, then Genucrassum bransatensis would provide a calibration for the basal divergence of crown Charadrii. 


\section{CLADE JACANIDAE}

\section{Node Calibrated (4): Jacanidae (Jesus birds)}

Divergence of Jacanidae (i.e., Jacana and Hydrophasianus, lily trotters) from other Scolopaci (e.g., Bartramia longicauda, Numenius minutus; Figure 1)

Fossil Taxon. Nupharanassa bulotorum Rasmussen et al., 1987

Specimen. DPC 3848 (Duke Lemur Center, Division of Fossil Primates, Durham, North Carolina, USA) holotype specimen of Nupharanassa bulotorum, distal tarsometatarsus.

Phylogenetic Justification. The results of a combined phylogenetic analysis place Nupharanassa bulotorum as the sister taxon to the extant species Hydrophasianus chirurgus (Smith, 2011a, figure 8.4). Although material referred to three Oligocene species of Jacanidae (including Nupharanassa bulotorum) consists entirely of distal tarsometatarsi, fossil jacanid species are characterized by the "huge distal foramen, broad tendinal groove, and flattened shaft unique to this family" (Rasmussen et al., 1987:7). The relatively enlarged distal vascular foramen was optimized as an apomorphy of Jacanidae and the possession of a broad anterior groove that extends proximally form the distal vascular foramen is optimized as an apomorphy of Jacanidae, Glareolidae, and Scolopacidae among charadriiforms sampled by Smith (2011a).

Minimum Age. Early Oligocene (Rupelian) 30.0 Ma

Soft Maximum Age. Not specified

Age Justification. Jacanidae fossils are known from quarries $M$ and $E$ (see Rasmussen et al., 1987) of the Jebel Qatrani Formation in Egypt, which span the period between $\sim 33-30 \mathrm{Ma}$. That age estimate has been established using biostratigraphic, radiometric, and magnetostratigraphic correlations (Seiffert, 2006 and references therein). Although remains of the jacanid Nupharanassa tolutaria are definitely older than Nupharanassa bulotorum, that taxon has not been included in a phylogenetic analysis and therefore, a more conservative date of $30.0 \mathrm{Ma}$ is suggested to calibrate the split between Jacanidae and other Scolopaci until the affinities of Nupharanassa tolutaria are better established.

Discussion. The oldest known fossils referable to the Jacanidae, and of the Scolopaci are from the Early Oligocene Jebel Qatrani Formation of Egypt (Rasmussen et al., 1987). However, because Nupharanassa bulotorum can be referred to a more nested position within Scolopaci, this fossil should not be used as a calibration for the split between Scolopaci and Lari. The enigmatic taxon Halcyornis topiapicus (sic, Halcyornis toliapicus) was used by Pereira and Baker (2008) to date the minimum age of divergence between the Lari and Scolopaci. The systematic position of $H$. toliapicus has not been previously evaluated in a phylogenetic analysis and $H$. toliapicus has been previously allied with charadriiforms, coraciiforms, and stem psittaciforms (reviewed by Smith and Clarke, 2012). The isolated holotype specimen of $H$. toliapicus consists of an incomplete cranium, and although current evidence supports placement of this taxon in Charadriiformes, endocranial characteristics may be too ecologically plastic (i.e., potentially phylogenetically misleading) to facilitate taxonomic referrals (Smith and Clarke, 2012). Therefore, because the true affinities of $H$. toliapicus remain uncertain, that specimen should not be used as a fossil calibration. Subsequently, because the taxonomic affinities of $H$. toliapicus remain uncertain, consideration should be given to resurrecting the taxon name Pseudasturidae Mayr 1998 for the stem Psittaciformes taxa known from Europe and North America (see Mayr, 2009; Ksepka et al., 2011).

Additional scolopacid taxa including Micropalama hesternus, Limosa gypsorum, and Numenius antiquus, have been applied as fossil calibrations within Charadriiformes (Baker et al., 2007; Cibois et al., 2012). Although those taxa and other fragmentary remains referred to the clade likely represent examples of fossil Scolopaci (reviewed by Mayr, 2009), none of those taxa can be confidently referred to extant genera (i.e., crown Scolopaci), and those fossils should not be used to calibrate node ages until their systematic positions can be more precisely established (Mayr, 2009; Smith, 2011a; De Pietri and Mayr, 2012).

\section{CLADE CROWN CALIDRIDINAE}

Node Calibrated (5): crown Calidridinae ('arctic sandpipers'). Basal divergence among crown Calidridinae (i.e., divergence of the 'arctic sandpipers' Aphriza, Calidris, Limicola, Tryngites, Eurynorhynchus, Philomachus, and Micropalama)

Fossil Taxon. Mirolia brevirostrata Ballmann, 2004 Specimen. 1970 XVIII Steinberg (Bayerische Staatssammlung für Paläontologie und Historische Geologie, Munich, Germany) holotype specimen of Mirolia brevirostrata, cranium.

Phylogenetic Justification. The holotype and referred specimens of Mirolia brevirostrata were referred to Calidridinae arctic sandpipers on the 
basis of apomorphic characters of the cranium and postcranium (Ballmann, 2004). The following apomorphies that support referral of Mirolia brevirostrata to Calidridinae were cited by Ballmann (2004:111): "the shallow and narrow origin of $\mathrm{m}$. depressor mandibulae on the cranium and the corresponding short processus retroarticularis; the relatively short bill, with a moderately reinforced dorsal bar; the shape of the processus supracondylaris dorsalis on the humerus; humerus about the same length as the tarsometatarsus." Although material referred to Mirolia brevirostrata has not been included in a phylogenetic analysis, the referral of material to this clade has not been questioned (De Pietri and Mayr, 2012).

Minimum Age. Middle Miocene (Serravallian) $11.62 \mathrm{Ma}$

\section{Soft Maximum Age. Not specified}

Age Justification. The Nördlinger Ries basin is an impact crater, and an absolute minimum age for the impact event was established at $14.8 \pm 0.7 \mathrm{Ma}$ based on radiometric methods (Ballmann, 2004). Fossils from the Nördlinger Ries basin have been dated to the Middle Miocene (Astaracian; MN 6; 16.0-11.6 Ma; i.e., Langhian-Serravallian) on the basis of faunal correlation (Ballmann, 2004). The exact age of the fossils has not been determined so a conservative strategy of using the age of the Serravallian-Tortonian boundary is recommended until more precise age estimates become available.

Discussion. Additional scolopacid fossils are younger than Mirolia brevirostrata or are of uncertain taxonomic affinity within Scolopacidae. For example, Limosa vanrossemi Miller, 1925 is from the Late Miocene of California and is in need of taxonomic re-evaluation. Although a putative Scolopacidae was described from the Early Oligocene of France by Roux (2002), the affinities of that specimen within Scolopacidae are not known. Given that an Early Oligocene jacanid provides a more nested calibration of similar age within Scolopacidae, the putative scolopacid described by Roux (2002) should not be used as a fossil calibration for divergence time analyses until its systematic position is further evaluated.

\section{CLADE TURNICIDAE}

Node Calibrated (6): Turnicidae (buttonquail). Divergence of Turnicidae (buttonquails) from Lari (gulls, terns, alcids, and skimmers; Figure 1)

Fossil Taxon. Turnipax oechslerorum Mayr and Knopf, 2007
Specimen. SMF Av 506a+b (Forschungsinstitut Senckenberg, Frankfurt, Germany) holotype specimen of Turnipax oechslerorum, partial postcranial skeleton.

Phylogenetic Justification. Turnipax represents the stem lineage of Turnicidae (buttonquails) and was originally referred to that clade based on apomorphic characters of the coracoid, scapula, furcula, and humerus (Mayr, 2000). In addition to characters cited by Mayr (2000), Mayr and Knopf (2007:775) cited the following apomorphies that support referral of species of Turnipax to Turnicidae: (1) impressio musculi sternocoracoidei on extremitas sternalis of coracoid deeply excavated; (2) processus procoracoideus very broad; (3) caudal margin of sternum with single pair of incisions; (4) incisura capitis of humerus with transverse ridge; (5) incisions in caudal margin of sternum proportionally shorter; (6) ulna long and slender; (7) carpometacarpus elongate, with straight os metacarpale minus; (8) presence of a short hallux. Although Turnipax oechslerorum has not been included in a phylogenetic analysis, no alternative hypothesis has been proposed linking this taxon to any clade other than Turnicidae.

Minimum Age. Early Oligocene (Rupelian) 30.0 Ma

Soft Maximum Age. Not specified

Age Justification. Geologic studies of the clay deposits of Frauenweiler, Germany have dated them to the Early Oligocene (MP22) and established an absolute age of 32.0-30.0 Ma for those deposits based on micropaleontological correlations (Micklich and Hildebrandt, 2005).

Discussion. Although the systematic affinities of buttonquail have long been disputed (i.e., alternatively considered part of Charadriiformes, Gruiformes, or Galliformes; del Hoyo et al., 1996), recent molecular sequence based analyses support Turnicidae as part of Charadriiformes (Baker et al., 2007; Hackett et al., 2008). Although fossils of Turnicidae (i.e., stem buttonquail) are known from the Early Oligocene ( $32 \mathrm{Ma})$ of France and Germany (Mayr, 2000; Mayr and Knopf, 2007), the systematic placement of the extant taxon Turnix remains an issue of contention (Baker et al., 2007; Hackett et al., 2008; Livezey, 2009, 2010). Therefore the node at which Turnipax oechslerorum is applied as a fossil calibration will depend on the topology of the phylogenetic tree being dated. The results of Baker et al. (2007) and Hackett et al. (2008) are congruent in their placement of Turnix as the sister taxon to Lari, and Turnipax oechslerorum is herein suggested as a potential fossil cali- 
bration for that node (i.e., the split between Turnix and Lari). Although, a more nested node within Lari can be assigned an older date (Alcidae divergence from Stercorariidae; see below), the systematic position of Turnicidae remains an issue of contention. Therefore, as stated above, use of Turnipax oechslerorum as a fossil calibration will depend on the hypothesis of relationships.

\section{CLADE LAROMORPHAE}

Node Calibrated (7): Laromorphae (auks, gulls, terns and allies). Basal Divergence of Laromorphae (i.e., basal divergence of the clade including Laridae, Sternidae, Rynchopidae, Gygis and Anous; Figure 1)

Fossil Taxon. Laricola elegans (Milne-Edwards, 1863)

Specimen. MNHN Av.4134 (Museum National d'Histoire Naturelle, Paris, France) lectotype specimen of Laricola elegans, humerus; hypodigm listed by De Pietri et al. (2011).

Phylogenetic Justification. Material referred to Laricola elegans was included in a combined phylogenetic analysis by Smith (2011a) and the morphology based analysis of De Pietri et al. (2011). Laricola elegans was placed in a polytomy with the extant species Larus marinus and Larus argentatus in the results of Smith (2011a, figure 8.5) and was recovered in an unresolved position at the base of Laromorphae (the clade including Laridae, Sternidae, Rynchopidae, Gygis and Anous) in the results of De Pietri et al. (2011). The relative systematic positions of Laridae, Sternidae and Rynchopidae to one another, Larus relative to other Laridae, and the positions of Gygis and Anous relative to other Laromorphae differ in the results of recent phylogenetic analyses (e.g., Baker et al., 2007; Smith, 2011b; De Pietri et al., 2011). Moreover, because the systematic position of Laricola was unresolved in the results of De Pietri et al. (2011), Laricola elegans is suggested as a calibration for the basal divergence among Laromorphae. Minimum Age. Late Oligocene (Chattian) 23.6 Ma Soft Maximum Age. Not specified

Age Justification. Laricola remains have been reported from localities in France including the Early Miocene of Saint-Gérand-le-Puy and from the Late Oligocene Billy-Créchy locale (MilneEdwards, 1863; Mourer-Chauviré et al., 2004; De Pietri et al., 2011). The vertebrate fauna from Créchy, France, corresponds with Paleogene mammalian zones MP25-MP30 and are considered to bracket the Miocene-Oligocene boundary with an age estimated between 24.1-23.6 Ma (Hugueney et al., 2003).

Discussion. Originally described as 'Larus elegans,' this taxon, along with 'Larus desnoyersii,' and 'Larus totanoides' were transferred into the newly erected genus Laricola by Mlikovsky (2002); Smith and Clarke, in press. The fossil calibration used by Baker et al. (2007) to date the Larus-Rissa split at 15.9 Ma is listed as $4 \mathrm{spp}$. of Larus and corresponds in Brodkorb (1967) to Laricola elegans, Laricola totanoides, and Laricola desnoyersii from the Early Miocene of France and Larus pristinus from the early Miocene of Oregon. The holotype specimen of Larus pristinus is an isolated proximal tibiotarsus. In addition to the fact that these taxa may or may not be coeval, the referral of 'Larus' desnoyersii and Larus pristinus to Laridae was questioned on the basis of osteological characteristics (Olson, 1985). The extensive taxonomic revision and material referred to species of Laricola by De Pietri et al. (2011) should facilitate future species level evaluation of taxa in that clade. However, Laricola elegans is the only Laromorphae taxon that is potentially complete enough to warrant inclusion in phylogenetic analysis and until the species-level affinities of Laricola elegans and other extinct Laromorphae can be further evaluated, a conservative approach with regard to the use of Laricola elegans as a fossil calibration is suggested (i.e., calibrating the basal divergence among Laromorphae).

\section{CLADE PAN-ALCIDAE - STERCORARIIDAE}

Node Calibrated (8): Pan-Alcidae (auks) - Stercorariidae (skuas). Divergence of Pan-Alcidae (auks) from Stercorariidae (skuas and jaegers; Figures 1, 2)

Fossil Taxon. Pan-Alcidae incertae sedis (Chandler and Parmley, 2002; Smith, 2011a)

Specimen. GCVP 5690 (Georgia College and State University Vertebrate Paleontology Collection, Milledgeville, GA, USA) distal humerus.

Phylogenetic Justification. GCVP 5690 was included in a combined analysis of morphological and molecular sequence data by Smith (2011a). The results of that analysis were inconclusive regarding the position of the taxon represented by GCVP 5690, hence the designation Pan-Alcidae incertae sedis. No alternative hypothesis has been proposed linking this specimen to any clade other than Pan-Alcidae. The sister taxon relationship between Pan-Alcidae and Stercorariidae is supported by analyses of morphological and molecular sequence data (Baker et al., 2007; Pereira and 
Baker, 2008; Smith, 2011a,b; Smith and Clarke, in press).

Minimum Age. Late Eocene (Priabonian) 34.2 Ma Soft Maximum Age. Not specified

Age Justification. The oldest fossil pan-alcid is from Late Eocene deposits of the Hardie Mine located in Gordon, Georgia USA (Chandler and Parmley, 2002). Fossils of sharks, rays, bony fishes, snakes, and the auk specimen (GCVP 5690) have been recovered from an approximately one meter thick, in situ bed of the Late Eocene Clinchfield Formation, a basal unit of the Barnwell Group (Huddelstun and Hetrick, 1986; Westgate, 2001). The Hardie Mine exposures of the Clinchfield Formation are a discrete fossiliferous unit with no evidence of mixing with older or younger bounding units (Parmley and Holman, 2003). Evidence from shark, mammalian, mollusk, and dinocyst assemblages support a Late Eocene age for the Clinchfield Formation sediments exposed at Hardie Mine (Parmley and Holman, 2003). The dinocyst assemblage is correlated with assemblages from other localities in Georgia and South Carolina that are placed in calcareous nannofossil zone NP 19/ 20 , and have been assigned an age of 36.0-34.2 Ma. Congruent with the criteria proposed by Parham et al. (2012), the youngest possible date (34.2 $\mathrm{Ma}$ ) is suggested here as a hard minimum bound on the age of divergence between crown Alcidae and Stercorariidae.

Discussion. This fossil has been used previously to date the minimum time of divergence between Pan-Alcidae and its sister taxon Stercorariidae (Smith, 2011a; Weir and Mursleen, 2012; Smith and Clarke, in press). GCVP 5690 displays the apomorphic dorsoventrally flattened shaft and proximally extended dorsal supracondylar process that distinguishes the humeri of pan-alcids from all other charadriiforms (see Smith, 2011a, figure 8.2, table 8.5). The fossil is otherwise too fragmentary (i.e., an isolated distal humerus) to provide details of potentially plesiomorphic character states within Pan-Alcidae but it nonetheless, provides the oldest unambiguous record of the clade. The next oldest fossils referred to the Pan-Alcidae are two fragmentary and isolated specimens from the Iwaki Formation in Japan that are in need of systematic re-evaluation (Ono and Hasegawa, 1991). Other previously reported records of Eocene and Oligocene Pan-Alcidae have been taxonomically reassigned to other clades (i.e., no longer considered pan-alcids). Species of Nautilornis Wetmore 1926 from the Early Eocene of Utah were referred to Presbyornithidae (Feduccia and McGrew, 1974) and Hydrotherikornis oregonus Miller 1931 from the Late Eocene of Oregon was referred to Procellariiformes (Chandler 1990a; Chandler and Parmley, 2002). Petralca austriaca from the Late Oligocene of Austria was referred to Gaviidae (Wijnker and Olson, 2009; Mayr, 2009). I have examined the holotype specimens of Petralca austriaca and Hydrotherikornis oregonus and concur with their removal from Pan-Alcidae.

Of the three previous divergence estimates that focused specifically on alcids (Pereira and Baker, 2008; Smith, 2011a; Weir and Mursleen, 2012) only that of Smith (2011a) provided justification for the calibrations used (i.e., apomorphybased specimen referrals and review of age determinations). Moreover, nearly every calibration employed by Pereira and Baker (2008) and Weir and Mursleen (2012) was incorrectly dated (e.g., a date of $11.6 \mathrm{Ma}$ assigned to 'Uria antiqua'), incorrectly taxonomically assigned (e.g., Cerorhinca dubia; see discussion of node 8 below), or arguably inappropriate for use as a calibration (i.e., external calibrations). The variability of calibrations used in those three analyses is evident in the range of resulting node age estimates. For example, the age of the basal split among crown Alcidae was estimated at $19.8 \mathrm{Ma}$ (Weir and Mursleen, 2012), 33.83 (Smith, 2011a), and 54.9 Ma (Pereira and Baker, 2008). Although some of the discrepancy between those estimates is likely due to utilization of different divergence estimation software [i.e., Multidivtime (Thorne and Kishino, 2002) versus BEAST Drummond et al., 2012)], this example highlights the importance of vetting fossils to be used as calibrations and the effect that calibration choice can have on results of divergence time analyses.

\section{CLADE AETHIINI - FRATERCULINI}

Node Calibrated (9): Aethiini (auklets) - Fraterculini (puffins). Divergence of Aethiini (auklets) from Fraterculini (puffins; Figure 2)

Fossil Taxon. Aethia barnesi Smith, 2013

Specimen. LACM 107031 (Los Angeles County Museum of Natural History, Los Angeles, California, USA) holotype specimen of Aethia barnesi, distal humerus.

Phylogenetic Justification. The systematic position of Aethia barnesi was established based on a combined analysis of morphological and molecular sequence data (Smith, 2011a; Smith, 2013). Aethia barnesi was placed at the base of an unresolved Aethiini clade. Aethia barnesi was alternatively placed in a polytomy with the extant species Aethia 
pygmaea and Aethia cristatella (Smith, 2013). Apomorphies supporting referral of $A$. barnesi to Aethiini are provided by Smith (2013). Because Aethia barnesi is older than known fossils of Fraterculini (Smith, 2011a; Smith, 2013), thus, it provides a hard minimum bound on the age of divergence between those clades.

Minimum Age. Late Miocene (Messinian) 6.7 Ma

Soft Maximum Age. Not specified

Age Justification. The vertebrate assemblages of the San Mateo Formation were reviewed by Barnes et al. (1981), who designated the lower assemblage, from which the holotype specimen of Aethia barnesi was recovered, the San Luis Rey River Local Fauna (SLRRLF). Age estimates for the SLRRLF based upon terrestrial mammal and marine bird fossils range from approximately 6.710.0 Ma (Late Miocene or Tortonian-Messinian equivalent; Barnes et al. 1981; Domning and Deméré, 1984; see discussion below regarding the age justification for Cepphus olsoni). Therefore, 6.7 $\mathrm{Ma}$ is suggested as a minimum age for the divergence of Aethiini from Fraterculini.

Discussion. Additional material referred to Aethiini (i.e., Aethia and Ptychoramphus) is considered too fragmentary for referral (e.g., Aethia rossmoori), can no longer be located (Aethia sp.; LACM $37686)$, or is younger in age than Aethia barnesi (e.g., Aethia storeri; reviewed by Smith, 2013).

Ptychoramphus tenuis Miller and Bowman, 1958 was used previously to date the divergence of Ptychoramphus from Aethia (Baker et al., 2007; Pereira and Baker, 2008; Weir and Mursleen, 2012). As the name implies, the distinction of Ptychoramphus tenuis as a separate species was, at best tenuous, and based only on its age. The Pliocene or Pleistocene (3.6-1.5 Ma) holotype specimen of Ptychoramphus tenuis is an operational equivalent of the extant species Ptychoramphus aleuticus (Smith, 2013), and is therefore inappropriate for use as a calibration because Aethia barnesi is older and potentially occupies a more deeply nested position in Aethiini (Smith, 2013).

\section{CLADE ATLANTIC PUFFIN - HORNED PUFFIN}

Node Calibrated (10): Atlantic Puffin - Horned Puffin. Divergence of the Atlantic Puffin Fratercula arctica from the Horned Puffin Fratercula corniculata (Figure 2)

Fossil Taxon. Fratercula aff. arctica

Specimen. USNM 490887 (Smithsonian Institution, National Museum of Natural History, Washington, DC, USA) humerus.
Phylogenetic Justification. Although never included in a phylogenetic analysis, specimens referred to Fratercula aff. arctica by Olson and Rasmussen (2001) and Smith et al. (2007) were scored into the morphological phylogenetic data matrix of Smith (2011a) and were determined to be operational equivalents of the extant exemplars of Fratercula arctica that were included in that combined phylogenetic analysis. Fratercula arctica and Fratercula corniculata have been recovered as sister taxa to the exclusion of the Tufted Puffin Fratercula cirrhata in analyses of morphological and molecular sequence data (Moum et al., 1994; Friesen et al., 1996; Thomas et al., 2004; Pereira and Baker, 2008; Smith, 2011a,b; Smith and Clarke, in press).

Minimum Age. Early Pliocene (Zanclean) 4.2 Ma

Soft Maximum Age. Not specified

Age Justification. The Early Pliocene Yorktown Formation has been assigned an age of $4.4 \pm 0.2$ Ma based on K/Ar dating of the Orionina vaughani assemblage zone, and correlated with planktonic foraminifera Zone N19 (Hazel, 1983).

Discussion. The Fraterculini consist of Cerorhinca and its sister taxon Fratercula. Although fossils have been previously referred to Cerorhinca, older fossil remains of Fratercula aff. arctica provide a minimum age of divergence for a more nested node in Fraterculini. (i.e., the divergence of $F$. arctica from $F$. corniculata). Additional remains referred to Fratercula are the same age (e.g., Fratercula aff. cirrhata from the Yorktown Fm.) or younger than Fratercula aff. arctica (e.g., Fratercula dowi, Guthrie et al., 1999). Putatively older remains of Fratercula reported by Howard (1978) can no longer be located and can therefore, not be systematically evaluated (discussed by Smith, 2011a). Fratercula remains from the Early Pliocene Kattendijk Sands Formation of Belgium (Dyke and Walker, 2005) have not been phylogenetically evaluated and no diagnostic characters were provided to support referral of those specimens to Fraterculini. Remains referred to Cerorhinca are either younger than Fratercula aff. arctica (e.g., Cerorhinca minor; Howard, 1971; Cerorhinca reai; Chandler, 1990b) or of uncertain taxonomic affinity (e.g., Cerorhinca spp.; Howard, 1968; Chandler 1990b; see phylogenetic analysis by Smith, 2011a).

The taxon Cerorhinca dubia Miller, 1925 has been used previously to date the divergence between Cerorhinca and Fratercula (Baker et al., 2007; Pereira and Baker, 2008; Weir and Mursleen, 2012). Cerorhinca dubia was described from 
the Middle Miocene Monterey Formation, and consists only of pelvic limb impressions (see Smith, 2011a, figure 4.2). That specimen was tentatively described as a new taxon based upon the relative proportions of the preserved elements as compared with Cerorhinca monocerata. The referral of that specimen to Cerorhinca is, as its name implies, dubious at best, and as such, it is inappropriate for use as a fossil calibration.

\section{CLADE CEPPHUS}

Node Calibrated (11): Cepphus (guillemots). Divergence of the Spectacled Guillemot Cepphus carbo from the Black Guillemot Cepphus grylle and the Pigeon Guillemot Cepphus columba (Figure 2)

Fossil Taxon. Cepphus olsoni Howard, 1982 Specimen. LACM 107032 (Los Angeles County Museum of Natural History, Los Angeles, California, USA) holotype specimen of Cepphus olsoni, humerus.

Phylogenetic Justification. The only phylogenetic assessment of the systematic position of Cepphus olsoni recovered it as the sister taxon of the extant species Cepphus carbo, with Cepphus grylle and Cepphus columba in unresolved positions at the base of Cepphus (combined analysis; Smith, 2011a).

Minimum Age. Late Miocene (Messinian) 6.7 Ma

Soft Maximum Age. Not specified

Age Justification. The vertebrate assemblages of the San Mateo Formation were reviewed by Barnes et al. (1981), who designated the lower assemblage the San Luis Rey River Local Fauna (SLRRLF), and the upper assemblage the Lawrence Canyon Local Fauna (LCLF). Based on biostratigraphic correlation of marine vertebrates and terrestrial mammals, the age of the younger LCLF has been proposed to be latest Miocene or earliest Pliocene $(\sim 5.0 \mathrm{Ma})$, and correlative with the Late Hemphillian North American Land Mammal Age (Domning and Deméré, 1984). Pan-Alcidae fossils, including the holotype humerus of Cepphus olsoni have been recovered from the older SLRRLF. Age estimates for the SLRRLF based upon terrestrial mammal and marine bird fossils range from approximately 6.7-10.0 Ma (Late Miocene or Tortonian-Messinian equivalent; Barnes et al., 1981; Domning and Deméré, 1984). Therefore, the minimum estimated age of $6.7 \mathrm{Ma}$ is suggested as a minimum age of divergence for the split between Cepphus carbo and other extant species of Cepphus.

Discussion. Although an older putative Cepphini fossil ( 14 Ma) was described by Wijnker and
Olson (2009) and included in the phylogenetic analysis of Smith (2011a), the position of Pseudocepphus teres as the sister taxon to the rest of Cepphini was not considered strongly supported in the results of that analysis. Furthermore, the affinities of Pseudocepphus teres were originally hypothesized to be closer to Alcini (i.e., Alca and Miocepphus), and morphological characters shared with Cepphus were considered convergent by Wijnker and Olson (2009). Until additional material representing Pseudocepphus teres is recovered and the systematic position of that taxon can be more confidently established, its application as a fossil calibration remains uncertain.

\section{CLADE CRAVERI'S MURRELET - XANTUS'S MURRELET}

Node Calibrated (12): Craveri's Murrelet - Xantus's Murrelet. Divergence of Craveri's Murrelet Synthliboramphus craveri from Xantus's Murrelet Synthliboramphus hypoleucus (Figure 2)

Fossil Taxon. Synthliboramphus rineyi Chandler, 1990b

Specimen. UCMP 61590 (University of California Museum of Paleontology, Berkeley, CA, USA) holotype specimen of Synthliboramphus rineyi, humerus.

Phylogenetic Justification. Synthliboramphus rineyi was recovered in a clade with Synthliboramphus hypoleucus and Synthliboramphus craveri in the results of a combined phylogenetic analysis of morphological and molecular sequence data (Smith, 2011a). The referral of Synthliboramphus rineyi to Synthliboramphus has not been questioned.

Minimum Age. Early Pleistocene (Calabrian) 1.5 Ma

Soft Maximum Age. Not specified

Age Justification. The age of the San Diego Formation sediments from which the holotype specimen of Synthliboramphus rineyi was recovered was reviewed by Wagner et al. (2001). Based on microfaunal analysis and correlation with mammalian and molluskan assemblages of known age, the age of San Diego Formation is estimated to range from 3.6-1.5 Ma (i.e., Middle Pliocene to Early Pleistocene; Piacenzian-Calabrian; Wagner et al., 2001). The San Diego Formation was divided into 7 stratigraphic sub-units by Wagner et al. (2001). Paleomagnetic analysis indicates that sub-unit two can be correlated with Gilbert Chron C2Ar and Gauss Chron C2An.3n boundary, which has been assigned an age of 3.6 Ma (Wagner et al., 2001). However, the provenance of the holotype speci- 
men within the San Diego Formation (i.e., what sub-unit it was collected from) is uncertain. Therefore the more conservative date of $1.5 \mathrm{Ma}$ is recommended with respect to the age assignment of this specimen for divergence time analyses.

Discussion. Because the holotype specimen of Synthliboramphus rineyi is a humerus, because there are no known associated specimens of this taxon, and because there are other pan-alcid taxa known from the San Diego Formation (Aethia, Brachyramphus, Cerorhinca, Mancalla) there was no basis for referral of additional remains (coracoids, ulna, tarsometatarsus) to this taxon by Chandler (1990b; discussed by Smith, 2011a). Therefore, this calibration must be based solely on the holotype specimen until associated remains of this taxon are discovered that would allow for referral of additional skeletal elements or until the stratigraphic range of Synthliboramphus rineyi is extended by recovery of additional remains referable to that taxon.

\section{CLADE MARBLED MURRELET - KITTLITZ'S MURRELET}

Node Calibrated (13): Marbled Murrelet - Kittlitz's Murrelet. Divergence of the Marbled Murrelet Brachyramphus marmoratus from Kittlitz's Murrelet Brachyramphus brevirostris (Figure 2)

Fossil Taxon. Brachyramphus dunkeli Chandler, 1990b

Specimen. SDSNH 24573 (San Diego Museum of Natural History, San Diego, California, USA) holotype specimen of Brachyramphus dunkeli, humerus.

Phylogenetic Justification. Brachyramphus dunkeli was placed as the sister taxon to Brachyramphus marmoratus with Brachyramphus brevirostris placed at the base of that clade in the results of a combined analysis of morphological and molecular sequence data (Smith, 2011a). No alternative systematic position for Brachyramphus dunkeli has been proposed.

Minimum Age. Early Pleistocene (Calabrian) 1.5 Ma

Soft Maximum Age. Not specified

Age Justification. Deposition of the San Diego Formation was established to span the period between 3.6-1.5 Ma (Wagner et al., 2001; see discussion of age justification for Synthliboramphus rineyi above).

Discussion. Just as with Synthliboramphus rineyi, in the absence of associated specimens, there was no basis for referral of additional skeletal elements to Brachyramphus dunkeli that were incomparable to the holotype specimen by Chandler (1990b; discussed by Smith, 2011a). Furthermore, as with Synthliboramphus rineyi, the stratigraphic provenance of the holotype specimen and the stratigraphic range of Brachyramphus dunkeli within the San Diego Fm. have not been established. Until additional material has been identified, the holotype specimen serves as the specimen of record for calibrating the divergence of Brachyramphus marmoratus from Brachyramphus brevirostris.

\section{CLADE DOVEKIE - MURRES}

Node Calibrated (14): Dovekie - Murres. Divergence of the Dovekie Alle alle from Uria (murres; Figure 2)

Fossil Taxon. Miocepphus bohaski Wijnker and Olson, 2009

Specimen. USNM 237142 (Smithsonian Institution, National Museum of Natural History, Washington, DC, USA) paratype specimen of Miocepphus bohaski, distal humerus.

Phylogenetic Justification. Miocepphus bohaski was recovered as part of a clade including other species of Miocepphus and the extant species Alle alle in a combined analysis of morphological and molecular sequence data, and the Miocepphus + Alle clade was supported as the nearest outgroup to Uria (Smith, 2011a; Smith and Clarke, 2011). The sister taxon relationship between Uria and Alle is also supported by the results of previous analyses of molecular sequence data (Thomas et al., 2004; Pereira and Baker, 2008).

Minimum Age. Early Miocene (Burdigalian) 15.97 $\mathrm{Ma}$

Soft Maximum Age. Not specified

Age Justification. The paratype specimen of Miocepphus bohaski was recovered from the lower Calvert Formation (Popes Creek Sand Member) in Hanover County, Virginia, which has been assigned an age of Lower Miocene (Burdigalian; 20.43-15.97 Ma) based on biostratigraphic correlation (de Verteuil and Norris, 1996). The timing of deposition of the Popes Creek Sand Member has been interpreted as being temporally close to the Burdigalian-Aquitanian boundary, and as a result, the age of Miocepphus bohaski was hypothesized to be closer to 20.0 Ma by Wijnker and Olson (2009). However, because age determinations for Miocepphus bohaski are based on biostratigraphic correlation rather than radiometrically derived dates, a more conservative approach is taken herein, and the minimum age provided is that of the Burdigalian-Langhian boundary (i.e., 15.97 Ma). The holotype specimen of Miocepphus 
bohaski (partial postcranial skeleton; USNM 237270) was recovered from the St. Leonard Member of the Choptank Formation, the age of which has been interpreted as late Middle Miocene (13.82-11.61 Ma; Serravalian) on the basis of biostratigraphic correlation (de Verteuil and Norris, 1996).

Discussion. Species of Miocepphus were previously included in phylogenetic analysis (Smith and Clarke, 2011, in press). The results of those analyses are congruent with previously proposed morphology-based interpretations of close systematic relationship between Alle and Miocepphus (Olson and Rasmussen, 2001; Wijnker and Olson, 2009).

\section{CLADE COMMON MURRE - THICK-BILLED MURRE}

Node Calibrated (15): Common Murre - Thickbilled Murre. Divergence of the Common Murre Uria aalge from the Thick-billed Murre Uria lomvia (Figure 2)

Fossil Taxon. Uria lomvia Linnaeus, 1758 (see Olson, 2013)

Specimen. CASG 71892 (California Academy of Sciences, San Francisco, CA, USA) partial postcranial skeleton.

Phylogenetic Justification. Referred to Uria lomvia based upon apomorphies of the coracoid and humerus (Olson, 2013). Although the specimen has not been included in a phylogenetic analysis, it would likely be an operational equivalent of specimens of Uria lomvia scored by Smith (2011a) and the referral of that specimen to Uria lomvia has not been questioned.

Minimum Age. Late Pliocene (Piacenzian) 2.6 Ma Soft Maximum Age. Not specified

Age Justification. The transgressive marine sequences that outcrop at Tolstoi Point, and from which the Uria remains were recovered, are interpreted as equivalent to the Bigbendian and Colvillian stages and the absolute ages have been established at 2.6-3.0 Ma on the basis of stratigraphic and biostratigraphic correlations (BrighamGrette and Carter 1992; Olson, 2013).

Discussion. An additional fossil record of Uria was described from the late Pleistocene of Maine by Marsh (1872). Uria affinis lacks any characters that differentiate it from modern species of Uria and may represent a fossil occurrence of one of those modern forms (Smith and Clarke, 2011). However, the occurrence of Uria lomvia in the Pliocene of Alaska pre-dates the occurrence of Uria affinis, and therefore, Uria affinis should not be considered for use as a fossil calibration.

\section{CLADE RAZORBILL AUK - GREAT AUK}

Node Calibrated (16): Razorbill Auk - Great Auk. Divergence of the Razorbill Auk Alca torda from the Great Auk Pinguinus impennis (Figure 2)

Fossil Taxon. Alca cf. torda Linnaeus, 1758 Specimen. USNM 237157 (Smithsonian Institution, National Museum of Natural History, Washington, DC, USA) humerus; Additional fossils referred to the extant species Alca torda are listed in Wijnker and Olson (2009) and in Smith and Clarke (2011, appendix 2).

Phylogenetic Justification. Alca and Pinguinus have been recovered as sister taxa in the results of analyses of morphological and molecular sequence data (Strauch 1985, Chandler 1990a; Moum et al. 2002; Baker et al. 2007; Pereira and Baker 2008; Smith and Clarke, 2011; Smith and Clarke, in press).

Minimum Age. Late Miocene (Tortonian) 7.246 Ma Soft Maximum Age. Not specified

Age Justification. Remains of Alca aff. torda from the "Little Cove Point Beds" of the St. Mary's Formation in Virginia, USA are the earliest records of Alca. The St. Mary's Fm. has been interpreted as Tortonian (11.62-7.246 Ma) in age on the basis of biostratigraphic correlation (de Verteuil and Norris, 1996). The earliest records of Pinguinus are from the Early Pliocene (4.4 Ma) of North Carolina (Olson and Rasmussen, 2001; Smith and Clarke, 2011).

Discussion. The fossil calibration used to date the split between Uria and Alca + Alle by Baker et al. (2007) is listed as Uria antiqua. The name of this taxon was changed to Alca antiqua by Olson and Rasmussen (2001) to reflect its affinities with that clade, and subsequently amended to Alca grandis by Olson (2007) because the name Alca antiqua was unavailable according to the international code of zoological nomenclature (International Commission on Zoological Nomenclature, 2000). Although the holotype specimen of Alca grandis cannot be definitively assigned an age because its exact provenience is not known, the age of Alca grandis is now considered to be Early Pliocene ( 4.4 Ma) rather than middle Miocene (11.6 Ma) based on the abundant remains of this taxon from the Pliocene Yorktown Formation of Beaufort County, North Carolina (Olson and Rasmussen, 2001; Smith and Clarke, 2011).

"The extension of the temporal range of an extant species into the Miocene prompts questions about both the longevity and diagnosability of species, though no discrete differences in size or morphology between Miocene and Pliocene fossils 
attributed to $A$. torda and extant $A$. torda specimens were noted in specimens examined." (Smith and Clarke, 2011:19). Regardless of the potential for cryptic species to lead to underestimation of species diversity, remains attributed to Alca aff. torda do provide a hard minimum bound on the age of the split between Alca and its sister taxon Pinguinus.

\section{ACKNOWLEDGMENTS}

I thank J. Clarke, C. Bell, D. Cannatella, T. Rowe and two anonymous reviewers for comments. This research was supported as part of "Collaborative Research: Wings to Flippers - Phylogenetics, character acquisition, and feather biomechanics in the evolution of wing-propelled diving (NSF DEB 0949897)," a National Evolutionary Synthesis Center Postdoctoral Fellowship (NESCent; NSF EF-0905606), and benefitted from conversations with the NESCent working group "Synthesizing and Databasing Fossil Calibrations: Divergence Dating \& Beyond (www.nescent.org/ cal/calendar_detail.php?id=674).

\section{REFERENCES}

Baker, A.J., Pereira, S.L., and Paton, T.A. 2007. Phylogenetic relationships and divergence times of Charadriiformes genera: multigene evidence for the Cretaceous origin of 14 clades of shorebirds. Biology Letters, 3:205-209.

Ballmann, P. 2004. Fossil Calidridinae (Aves: Charadriiformes) from the Middle Miocene of the Nördlinger Ries. Bonner Zoologische Beiträge, 52:101-114.

Barnes, L.G., Howard, H., Hutchison, J.H., and Welton, B.J. 1981. The vertebrate fossils of the marine Cenozoic San Mateo Formation at Oceanside, California, p. 53-70. In Abbott, P.L. and O'Dunn, S. (eds.), Geologic Investigations of the Coastal Plain. San Diego Association of Geologists, San Diego.

Bickart, K.J. 1981. A new thick-knee, Burhinus, from the Miocene of Nebraska, with comments on the habitat requirements of the Burhinidae (Aves: Charadriiformes). Journal of Vertebrate Paleontology, 1:273277.

Brigham-Grette, J. and Carter, L.D. 1992. Pliocene marine transgressions of northern Alaska: circumarctic correlations and paleoclimatic interpretations. Arctic, 45:74-89.

Brodkorb, P. 1967. Catalogue of fossil birds: Part 3 (Ralliformes, Ichthyornithiformes, Charadriiformes). Bulletin of the Florida State Museum, Biological Sciences, 11:99-220.

Brown, J.W., Payn, R.B., and Mindell, D.P. 2007. Nuclear DNA does not reconcile 'rocks' and 'clocks' in Neoaves: a comment on Ericson et al. Biology Letters, 3:257-259.
Chandler, R.M. 1990a. Phylogenetic analysis of the alcids. Doctoral Dissertation, University of Kansas, Lawrence Kansas.

Chandler, R.M. 1990b. Fossil birds of the San Diego Formation, Late Pliocene, Blancan, San Diego County California. Ornithological Monographs, 44:73-161.

Chandler, R.M. and Parmley, D. 2002. The earliest North American record of an auk (Aves: Alcidae) from the Late Eocene of central Georgia. Oriole, 68:7-9.

Cibois, A., Dekker, R.W.R.J., Pasquet, E., and Thibault, J. 2012. New insights into the systematics of the enigmatic Polynesian sandpipers Aechmorhynchus parvirostris and Prosobonia leucoptera. Ibis, 154:756-767.

Clarke, J.A. and Norell, M.A. 2002. The morphology and phylogenetic position of Apsaravis ukhaana from the Late Cretaceous of Mongolia. American Museum Novitates, 3387:1-46.

del Hoyo, J., Elliot, A., and Sargatal, J. (eds.) 1996. Handbook of the Birds of the World. Vol 3. Hoatzins to Auks. Lynx Edicions, Barcelona, Spain.

De Pietri, V.L. and Mayr, G. 2012. An assessment of the diversity of Early Miocene Scolopaci (Aves, Charadriiformes) from Saint-Ge 'Rand-Le-Puy (Allier, France). Palaeontology, 55:1177-1197.

De Pietri, V.L., Costeur, L., Guntert, M., and Mayr, G. 2011. A revision of the Lari (Aves, Charadriiformes) from the early Miocene of Saint-Gérand-le-Puy (Allier, France). Journal of Vertebrate Paleontology, 31:812-828.

De Pietri, V.L., and Scofield, R.P. 2013. The earliest record of a stone-curlew (Charadriiformes, Burhinidae) from the late Oligocene of France. Journal of Ornithology, DOI 10.1007/s10336-013-1022-8.

de Verteuil, L. and Norris, G. 1996. Dinoflagellate cyst zonation and allostratigraphy of the Chesapeake Group, p. 1-82. In de Verteuil, L. and Norris, G. (eds.), Miocene Dinoflagellate Stratigraphy and Systematics of Maryland and Virginia. Micropaleontology, 42 (supplement). American Museum of Natural History, New York.

Domning, D.P. and Deméré, T.A. 1984. New material of Hydrodamilis cuestae (Mammalia: Dugonidae) from the Miocene and Pliocene of San Diego County, California. Transactions of the San Diego Society of Natural History, 20:169-188.

Drummond, A.J., Rambaut, A., and Suchard, M. 2012. BEAST v1.7.3 Bayesian evolutionary analysis sampling trees. Available from http://evolve.zoo.ox.ac.uk/ beast/.

Dyke, G.J. and Walker, C.A. 2005. New records of fossil birds from the Pliocene of Kallo, Belgium, Nues Jahrbuch für Geologie und Paläeontologie, 200:233-247.

Ericson, P.G.P., Anderson, C.J., Britton, T., Elzanowski, A., Johansson, U.S., Kallersjo, M., Ohlson, J.I., Parsons, T.J., Zuccon, D., and Mayr, G. 2006. Diversification of Neoaves: integration of molecular sequence data and fossils. Biology Letters, 2:543-547. 
Feduccia, A. 1996. The origin and evolution of birds, 2nd ed. Yale University Press, New Haven.

Feduccia, A. and McGrew, P.O. 1974. A flamingo-like wader from the Eocene of

Wyoming. University of Wyoming Contributions to Geology, 13:49-61.

Friesen, V., Baker, A., and Piatt, J. 1996. Phylogenetic relationships within the Alcidae (Charadriiformes: Aves) inferred from total molecular evidence. Molecular Biology and Evolution, 13:359-367.

Guthrie, D., Thomas, H., and Kennedy, G. 1999. A new species of extinct Late Pleistocene puffin (Aves: Alcidae) from the southern California Channel Islands. Proceedings of the Fifth California Islands Symposium. US Dept. of Interior, Minerals Management Service, Pacific OCS Region (published as CD), MMS 99-0038.

Hackett, S.J., Kimball, R.T., Reddy, S., Bowie, R.C.K., Braun, E.L., Braun, M.J., Chojnowski, J. L., Cox, W.A., Han, K., Harshman, J., Huddleston, C.J., Marks, B.D., Miglia, K.J., Moore, W.S., Sheldon, F.H., Steadman, D.W., Witt, C.C., and Yuri, T. 2008. A phylogenomic study of birds reveals their evolutionary history. Science, 320:1763-1768.

Harrison, C.J.O. and Walker, C.A. 1977. Birds of the British lower Eocene. Tertiary Research, Special Paper, 3:1-32.

Hazel, J. 1983. Age and correlation of the Yorktown (Pliocene) and Croatan (Pliocene and Pleistocene) Formations at the Lee Creek Mine. Smithsonian Contributions to Paleobiology, 53:81-200.

Hope, S. 2002. The Mesozoic radiation of neornithes, $p$. 339-388. In Chiappe, L.M. and Witmer, L.M. (eds.), Mesozoic Birds: above the heads of dinosaurs. University of California Press, Berkeley.

Hou, L. and Ericson, P.G.P. 2002. A Middle Eocene shorebird from China. Condor, 104:896-899.

Howard, H. 1968. Tertiary birds from Laguna Hills, Orange County, California. Los Angeles County Museum Contributions to Science, 142:1-21.

Howard, H. 1971. Pliocene avian remains from Baja California. Los Angeles County Museum Contributions to Science, 217:1-17.

Howard, H. 1978. Late Miocene marine birds from Orange County, California. Natural History Museum of Los Angeles County Contributions to Science, 290:1-26.

Howard, H. 1982. Fossil birds from the Tertiary marine beds at Oceanside, San Diego County, California, with descriptions of two new species of the genera Uria and Cepphus (Aves: Alcidae). Natural History Museum of Los Angeles County Contributions to Science, 341:1-15.

Huddelstun, P.F. and Hetrick, J.H. 1986. Upper Eocene stratigraphy of central and eastern Georgia. Georgia Geologic Survey Bulletin, 95:1-78.
Hugueney, M., Berthet, D., Bodergat, A., Escuillié, F., Mourer-Chauviré, C., and Wattinne, A. 2003. The Oligocene-Miocene boundary in Limagne: faunal changes in the mammals, birds and ostracods from the different levels of Billy-Créchy (Allier, France). Geobios, 36:719-731.

International Commission on Stratigraphy. 2012. International Chronostratigraphic Chart. www.stratigraphy.org.

International Commission on Zoological Nomenclature. 2000. International Code of Zoological Nomenclature, 4th ed., International Trust for Zoological Nomenclature.

Ksepka, D.T. and Clarke, J.A. 2009. Affinities of Palaeospiza bella and the phylogeny and biogeography of mousebirds (Coliiformes). Auk, 126:245-259.

Ksepka, D.T., Clarke, J.A., and Grande, L. 2011. Stem parrots (Aves, Halcyornithidae) from the Green River Formation and a combined phylogeny of PanPsittaciformes. Journal of Paleontology, 85:835-852.

Linnaeus, C. von. 1758. Systema naturae per regna tria naturae, secundum classes, ordines, genera, species, cum characteribus, differentiis, synonymis, locis. Editio decima, reformata. Holmiae. Laurentii Salvii. [1-4], 1-824.

Livezey, B.C. and Zusi, R.L. 2006. Higher-order phylogeny of modern birds (Theropoda, Aves: Neornithes) based on comparative anatomy: I. methods and characters. Bulletin of the Carnegie Museum of Natural History, 37.

Livezey, B.C. and Zusi, R.L. 2007. Higher-order phylogeny of modern birds (Theropoda, Aves: Neornithes) based on comparative anatomy: II. analysis and discussion. Zoological Journal of the Linnean Society, 149:1-95.

Livezey, B.C. 2009. Phylogenetics of modern shorebirds (Charadriiformes) based on phenotypic evidence: I, characterization. Bulletin of the Carnegie Museum of Natural History, 40:1-96.

Livezey, B.C. 2010. Phylogenetics of modern shorebirds (Charadriiformes) based on phenotypic evidence: II, analysis and discussion. Zoological Journal of the Linnean Society, 160:567-618.

Marsh, O.C. 1872. Notice of some new Tertiary and postTertiary birds. American Journal of Sciences, 34:256262.

Mayr, G. 1998. A new family of Eocene zygodactyl birds. Senckenbergiana Lethaea, 78:199-209.

Mayr, G. 2000. Charadriiform birds from the Early Oligocene of Céreste (France) and the Middle Eocene of Messel (Hessen, Germany). Geobios, 33:625-636.

Mayr, G. 2005. The Paleogene fossil record of birds in Europe. Biological Review, 80:515-542.

Mayr, G. 2009. Paleogene Fossil Birds. Springer-Verlag, Heidelberg.

Mayr, G. 2011. The phylogeny of charadriiform birds (shorebirds and allies) - reassessing the conflict between morphology and molecules. Zoological Journal of the Linnaean Society, 161:916-934. 
Mayr, G. and Clarke, J. 2003. The deep divergences of neornithine birds: a phylogenetic analysis of morphological characters. Cladistics, 19:527-553.

Mayr, G. and Knopf, C.W. 2007. A stem lineage representative of buttonquails from the lower Oligocene of Germany - fossil evidence for a charadriform origin of the Turnicidae. Ibis, 149:774-782.

Mertz, D.F. and Renne, P.R. 2005. A numerical age for the Messel fossil deposit (UNESCO World Heritage Site) derived from 40Ar/39Ar dating on a basaltic rock fragment. Courier Forschungsinstitut Senckenberg, 255: 67-75.

Micklich, N. and Hildebrandt, L. 2005. The Frauenweiler clay pit ('Grub Unterfeld'). Kaupia: Darmstädter Beiträge Naturgesch, 14:113-118.

Miller, L. 1925. Avian remains from the Miocene of Lompoc, California. Carnegie Institution of Washington, Contributions to Paleontology, 349:107-117.

Miller, A.H. 1931. An auklet from the Eocene of Oregon. University of California Publications, Bulletin of the Department of Geological Sciences, 20:23-26.

Miller, L. and Bowman, R.I. 1958. Further bird remains from the San Diego Pliocene. Los Angeles County Museum Contributions in Science, 20:4-15.

Milne-Edwards, A. 1863. Memoire sur la distribution géologique des oiseaux fossiles et description de quelques espéces nouvelles. Annales des Sciences Naturelles, 20, 132-176.

Mlíkovský, J. 2002. Cenozoic birds of the world. Part 1: Europe. Ninox Press, Praha.

Moum, T., Àrnason, U., and Àrnason, E. 2002. Mitochondrial DNA sequence evolution and phylogeny of the Atlantic Alcidae, including the extinct Great Auk (Pinguinus impennis). Molecular Biology and Evolution, 19:1434-1439.

Moum, T., Johansen, S., Erikstad, K.E., and Piatt, J.F. 1994. Phylogeny and evolution of the auks (subfamily Alcinae) based on mitochondrial DNA sequences. Proceedings of the National Academy of Sciences, 91:7912-7916.

Mourer-Chauviré, C., Berthet, D., and Hugueney, M. 2004. The Late Oligocene birds of the Créchy quarry (Allier, France) with a description of two new genera (Aves: Pelicaniformes: Phalacrocoracidae, and Anseriformes: Anseranatidae). Senckenbergiana Lethaea, 84:303-315.

Olson, S.L. 1985. The fossil record of birds, p. 79-252. In Farmer, D.S. and King, A. (eds.), Avian Biology vol. 8. Academic Press, Orlando.

Olson, S.L. 1999. Early Eocene birds from eastern North America: a faunule from the Nanjemoy Formation of Virginia. p. 123-132. In Weems, R.E. and Grimsley G.J. (eds.), Early Eocene Vertebrates and Plants From the Fisher/Sullivan Site (Nanjemoy Formation) Stafford County Virginia. Virginia Division of Mineral Resources Publication 152.

Olson, S.L. 2007. Alca antiqua (Marsh, 1870), an invalid combination for a fossil auk (Alcidae). Bulletin of the British Ornithological Club, 127:225.
Olson, S.L. 2013. A Late Pliocene Occurrence of the Thick-billed Murre (Alcidae: Uria lomvia) on St. George Island, Pribilofs, Alaska. Paleontological Journal, 147:1365-1368.

Olson, S.L. and Parris, D.C. 1987. The Cretaceous birds of New Jersey. Smithsonian Contributions to Paleobiology, 63:1-22.

Olson, S.L. and Rasmussen, P.C. 2001. Miocene and Pliocene birds from the Lee Creek Mine, North Carolina. Smithsonian Contributions to Paleobiology, 90:233-365.

Ono, K. and Hasegawa, Y. 1991. Vertebrate fossils of the Iwaki Formation, 1; avian fossils, p. 6-8, 15-16. In Koda, Y. (ed.), The Excavation Research Report of the Animal Fossils of the Iwaki Formation, Iwaki City, Japan.

Parham, J.F., Donoghue, P.C.J., Bell, C.J., Calway, T.D., Head, J.J., Holroyd, P.A., Inoue, J.G., Irmis, R.B., Joyce, W.G., Ksepka, D.T., Patané, J.S.L., Smith, N.D., Tarver, J.E., Van Tuinen, M., Yang, Z., Angielczyk, K.D., Greenwood, J., Hipsley, C.A., Jacobs, L., Makovicky, P.J., Müller, J., Smith, K.T., Theodor, J.M., Warnock, R.C.M., and Benton, M.J. 2012. Best practices for justifying fossil calibrations. Systematic Biology, 61:346-359.

Parmley, D. and Holman, J.A. 2003. Nebraskophis HOLMAN from the late Eocene of Georgia (USA), the oldest known North American colubrid snake. Acta Zoologica Cracoviensia, 46:1-8.

Paton, T.A., Haddrath, O., and Baker, A.J. 2002. Complete mitochondrial DNA genome sequences show that modern birds are not descended from transitional shorebirds. Proceedings of the Royal Society of London B, 269:839-846.

Paton, T.A., Baker, A.J., Groth, J.G., and Barrowclough, G.F. 2003. RAG-1 sequences resolve phylogenetic relationships within charadriiform birds. Molecular Phylogenetics and Evolution, 29:268-278.

Pereira, S.L. and Baker, A.J. 2006. A mitogenic timescale for birds detects variable phylogenetic rates of molecular evolution and refutes the standard molecular clock. Molecular Biology and Evolution, 23:17311740.

Pereira, S.L. and Baker, A.J. 2008. DNA evidence for a Paleocene origin of the Alcidae (Aves: Charadriiformes) in the Pacific and multiple dispersals across northern oceans. Molecular Phylogenetics and Evolution, 46:430-455.

Rasmussen, D.T., Olson, S.L., and Simons, E.L. 1987. Fossil birds from the Oligocene Jebel Qatrani Formation, Fayum Province, Egypt. Smithsonian Contributions to Paleobiology, 62.

Rich, P.V. and Bohaska, D.J. 1976. The world's oldest owl: a new strigiform from the Paleocene of southwestern Colorado. Smithsonian Contributions to Paleobiology, 27:87-93.

Roux, T. 2002. Deux fossiles d'oiseaux de l'Oligocéne inférieur du Luberon. Courrier Scientifique du Parc Naturel Régional du Luberon, 6:38-57. 
Seiffert, E.R. 2006. Revised age estimates for the later Paleogene mammal faunas of Egypt and Oman. Proceedings of the National Academy of Sciences, 103:5000-5005.

Slack, K.E., Jones, C.M., Ando, T., Harrison, G.L.R., Fordyce, E., Arnason, U., and Penny, D. 2006. Early penguin fossils, plus mitochondrial genomes, calibrate avian evolution. Molecular Biology and Evolution, 23:1144-1155.

Smith, N.A. 2011a. Systematics and evolution of extinct and extant Pan-Alcidae (Aves, Charadriiformes): combined phylogenetic analyses, divergence estimation, and paleoclimatic interactions. PhD Dissertation. The University of Texas at Austin.

Smith, N.A. 2011b. Taxonomic revision and phylogenetic analysis of the flightless Mancallinae (Aves, PanAlcidae). Zookeys, 91:1-116.

Smith, N.A. 2013. The fossil record and phylogeny of the auklets (Pan-Alcidae, Aethiini). Journal of Systematic Palaeontology. DOI: 10.1080/ 14772019.2012 .742147$.

Smith, N.A. and Clarke, J.A. 2011. An alphataxonomic revision of extinct and extant razorbills (Aves, Alcidae): a combined morphometric and phylogenetic approach. Ornithological Monographs, 72:1-61.

Smith, N.A. and Clarke, J.A. 2012. Endocranial Anatomy of the Charadriiformes: Sensory System Variation and the Evolution of Wing-Propelled Diving. Plos One, 7(11): e49584.

Smith, N.A. and Clarke, J.A. in press. Systematics and evolution of the Pan-Alcidae (Aves, Charadriiformes). Journal of Avian Biology.

Smith, N.A., Olson, S.L., and Clarke, J.A. 2007. First Atlantic record of the puffin Cerorhinca (Aves, Alcidae) from the Pliocene of North Carolina. Journal of Vertebrate Paleontology, 27:1039-1042.
Strauch, J.G. 1985. The phylogeny of the Alcidae. Auk, 102:520-539.

Thomas, G., Wills, M.A., and Szekely, T. 2004. Phylogeny of shorebirds, gulls and alcids (Aves: Charadrii) from the cytochrome-b gene: parsimony, Bayesian inference, minimum evolution and quartet puzzling. Molecular Phylogenetics and Evolution, 30:516-526.

Thorne, J.L. and Kishino, H. 2002. Divergence time and evolutionary rate estimation with multilocus data. Systematic Biology, 51:689-702.

Wagner, H.M., Riney, B.O., Deméré, T.A., and Prothero, D.R. 2001. Magnetic stratigraphy and land mammal biochronology of the nonmarine facies of the Pliocene San Diego Formation, San Diego County, California, p. 359-368. In Magnetic Stratigraphy of the Pacific Coast Cenozoic. Pacific Section SEPM, Book 91.

Weir, J.T. and Mursleen, S. 2012. Diversity dependent cladogenesis and trait evolution in the adaptive radiation of the auks (Aves: Alcidae). Evolution, DOI: 10.1111/j.1558-5646.2012.01786.x.

Westgate, J.W. 2001. Paleoecology and biostratigraphy of marginal marine gulf coast Eocene vertebrate localities, p. 263-297. In Gunnell, G.F. (ed.), Eocene Biodiversity: unusual occurrences and rarely sampled habitats. Kluwer Academic/Plenum Press, New York.

Wetmore, A. 1926. Fossil birds from the Green River deposits of eastern Utah. Annals of the Carnegie Museum, 16:391-402.

Wijnker, E. and Olson, S.L. 2009. A revision of the fossil genus Miocepphus and other Miocene Alcidae (Aves: Charadriiformes) of the western north Atlantic Ocean. Journal of Systematic Palaeontology, 7:471487. 